\title{
FARMER EXCHANGE RATE, GOVERNMENT EXPENDITURE ON EDUCATION AND GOVERNMENT EXPENDITURE ON HEALTH OF THE HUMAN DEVELOPMENT INDEX IN NORTH SUMATERA PROVINCE
}

\author{
Zulkarnain Nasution ${ }^{1)}$; Khairul Rizal' $\left.{ }^{2}\right)$ Junita Lubis ${ }^{3)}$ \\ 1) Faculty of Economics and Business, University of Labuhanbatu \\ 2) Faculty of Science and Technology, University of Labuhanbatu \\ 3) Faculty of Economics and Business, University of Labuhanbatu \\ Email: zulkarnainnasution1974@gmail.com
}

\section{How to Cite :}

Nasution, Z.; Rizal, Khairul. Lubis, Junita Effect Term of Trades, Government Expenditure On Education and Government Expenditure On Health of The Human Development Index in North Sumatera Province. Journal of Agri Socio-Economics and Business. 3 (1): 21-32. DOI: https://doi.org/10.31186/jaseb.03.1.21-32

\section{ARTICLE HISTORY}

Received [29 March 2021]

Revised [17 May 2021]

Accepted [01 June 2021]

\section{KEYWORDS}

Human development index,

Farmer exchange rate, Government expenditure for education and government expenditure forh health,

This is an open access article under the $C C-B Y-S A$ license

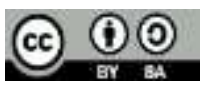

\section{ABSTRACT}

Human development is one of the factors in increasing the implementation of national development. Human development that is carried out can be calculated with the level of human health and standard of living. Then the level of the human development index can also affect the value of increasing per capita income and economic growth. The use of the model in this article was processed with the multiple linear regression program and classical assumptions test data using SPSS 22. The results of the analysis produce farmer value added (X1) which can significantly affect the human development index $(Y)$ in North Sumatra Province, government spending in the education sector (X2) can significantly affect the Human Development Index $(Y)$ in North Sumatra Province and government spending on health sector expenditures (X3) has no significant effect on the Human Development Index $(Y)$ in North Sumatra Province. It shows that government spending in the health sector (X3) has not been properly realized so that it is not strong enough to increase the Human Development index in North Sumatra Province. The results of the research on government spending in the education sector (X1) have a dominant effect in increasing the human development index in the province of North Sumatera. 


\section{INTRODUCTION}

Human resource is one of the most important factors in a development process and economy. In today's era, the domestic economy inevitably has to face the challenges of globalization. If this globalization is not followed by an increase in support, such as quality human resources, it will result in losing in global competition. Available job opportunities, in any sector, have the most important requirements to recruit employees or workers who have quality, namely the human resources that must be high. But the reality is that in North Sumatra, the quality of existing human resources is not in accordance with global demands and is not balanced with the use of natural resources or the diversity of existing natural resources. This is evident in the regions (Nias, Mandailing Natal, South Tapanuli, Central Tapanuli, Asahan, South Nias, Humbang Hasundutan, Pakpak Bharat, Batu Bara, Padang Lawas Utara, Padang Lawas, West Nias, North Nias and Tanjung balai), where The district's Human Development Index (HDI) is still below other cities / regencies in North Sumatra Province. In fact, the province of North Sumatra has the potential for natural resources that can be developed to increase the existence and development of the region. North Sumatra Province can develop development in the fields of industrialization, trade, tourism and agriculture. However, due to the low quality of human resources and the lack of intellectuals who are able to contribute their creative power for development in various sectors, this has resulted in the North Sumatra economy being unable to grow optimally.

According to Lugastoro, (2013), economic growth and human development (HDI) have a mutually supportive relationship that is mutually reinforcing due to government interference. When having a relationship that affects each other, economic growth and HDI will be strong, they support each other. However, when the variables have a weak relationship with each other, it will disturb each other and cause harm to each other. Therefore, the increase in economic growth and HDI must be balanced so that the national development goals can be achieved. The people of North Sumatra, who mostly live in rural areas, depend on the agricultural sector for their economy. In fact, the North Sumatra government has stated that it will encourage industrialization in the agricultural sector so that North Sumatra farmers get added value. This is because the agricultural sector is one of the direct and indirect livelihoods for rural communities in North Sumatra and has contributed greatly to increasing economic growth which is one of the factors used to increase HDI.

In addition, the production process in the agricultural sector which still uses traditional and simple methods causes less optimal production in this sector, so that agricultural production is unable to meet the needs of the people of East Java as a whole. Things like a problem for the people of East Java in fulfilling their daily needs. To carry out an optimal production process in this agricultural sector, quality human resources are needed. In addition to optimizing the production process in the agricultural sector, the quality of human resources is also indirectly able to influence in increasing the Farmer Exchange Rate (FER) which is an indicator of the welfare level of the farmer. If the FER value is low, it will result in a low impact on the ability of farmers to meet household consumption (especially consumption in the education and health sectors). So that the production process is needed in the agricultural sector and in an effort to improve the quality of human resources will experience disruption. 
Economic growth is a process in which there is an increase in real gross national product or real national income. So an economy can be said to grow or develop when there is growth in real output. Another definition of economic growth is that economic growth will occur if there is an increase in per capita output. Economic growth will describe that there will be an increase in the standard of living which can be measured by the amount of real output per person. While in poor countries which are very densely populated and many live on the borderline of life and have difficulty fulfilling their needs, developed countries enjoy a high and always increasing level of living. With this regard, the regional expenditure allocation strategy must be able to play an equally important role in increasing regional revenues. In an effort to increase it is expected that there will be a public contribution to regional revenues, the allocation of capital expenditures should be further increased. The regional government in the capital expenditure that is carried out includes for development activities and improvements in the education, health and transportation sectors, so that the community can enjoy the benefits of regional development activities.

The capital expenditure budget is calculated so that regional needs for the activity of building facilities and infrastructure can run smoothly for the smooth implementation of government tasks and for public facilities. Therefore, in an effort to improve the quality of public services, local governments should change the composition of their spending. So far, regional expenditure flow have been mostly used for routine ependiture purposes which are relatively unproductive. Using the expenditure budget should be allocated for productive purposes, for example for expenditures for development activities, in other words, capital expenditures are made in the context of capital formation which adds to fixed assets / inventory which can benefit people whose activities are carried out for more than one accounting period, this includes expenses for maintenance costs which maintain or increase benefits and increase the capacity and quality of assets. Based on the explanation above, it shows that the human development index, that economic growth and operational expenditure can simultaneously affect the amount of capital expenditure allocations. The human development index reflects a development activity carried out from a variety of infrastructure and infrastructure development activities that can improve the physical and non-physical quality levels of the community as well as improve community welfare in terms of education, health and the need for adequate housing availability. For this, the North Sumatra government requires an allocation of capital expenditures to realize the achievement of a good human development index.

Human Development Index (HDI) is an activity in assessing human development activities. This calculation system was introduced by an economist named Amartya Send and assisted by Mahbub UI Hag, (1999) so that this index is often called the Sen Index. HDI includes 3 (three) activities that are considered fundamental to human needs and can be operationally calculated to produce a measure that reflects the human development index. These three aspects are related to longevity, knowledge, and decent living (BPS, 2012).(Statistics, 2019)

Farmer Exchange Rate (FER) is a comparison between the price index received by farmers (IT) with the price index paid by farmers (IB) as a percentage. Farmers' exchange rate indicators are also used to measure the level of community welfare or the ability of farmers' purchasing power (Center of Statistic Bureau 2011).

In general, there are three definitions of the Farmers Exchange Rate Ruauw, (2010) First, if the NTP> 100, it means that the farmer experiences a surplus, the 
production price rises greater than his consumption. Farmers' income increased more than their expenses. Thus the level of farmer welfare will be better than the previous level of farmer welfare. Second, NTP $=100$, it means that the farmers break even. The occurrence of an increase or decrease in the price of manufactured goods must be equal to the percentage increase or decrease in the price of goods consumed. The welfare level of farmers has not changed. Third, NTP $<100$, it means that the farmers are experiencing a deficit. An increase in the price of a manufactured good will be relatively small when compared to an increase in the price of a consumer good. The level of welfare of farmers in a period will experience a level of decline when compared to the level of welfare of farmers in the previous period. The essence of agricultural development activity is to improve the welfare of the people in the agricultural sector. Given that the agricultural sector is a sector that is related to people's lives. According to Simatupang, (1992) agriculture is a local resource-based economic sector that has a significant role in the development of a country, especially developing countries such as Indonesia.

Napitupulu, (2007), HDI is one of the benchmarks for the development of an area that is negatively correlated with poverty conditions. In that region, because it is expected that an area with a high HDI value, ideally the quality of life of the community is high or it can also be said that if the HDI value is high, poverty should be low. The quality of human resources can also be a contributing factor to poor people. The quality of human resources can be seen from the Human Development Index (HDI). The low HDI will result in low work productivity of the population. Low work productivity results in low income generation. So that low income causes a high number of poverty. From the description of the background phenomenon, the problem formulation in this studi is as follow : Do farmers exchange rate, government spending on education and government spending on health together have a significant effect, against the human development indeks in north Sumatera province ?, among the three independent variable, which one has the dominant influence on the human development indek ? research purposes among others to determine the farers exchange rate, government spending on education and government spending on health together have a significant effect, againt the human development indeks in North Sumatera province, among the three independent variable, which one has the dominant influence on the human develeopment indeks From the description of the background phenomenon, the problem formulation in this study is as follows Do farmers exchange rates, government spending on education and government spending on health together have a significant effect. against the Human Development Index in North Sumatra Province? Among the three independent variables, which one has the dominant influence on the human development index?

\section{RESEARCH METHODS}

\section{Research Variable}

\section{The independent Variable use is}

Farmers Exchange Rates (FER), Education and Government Expenditures ( EGE) and Health and Government Expenditures (HGE) 


\section{The dependent Variable use is}

Human Development Index (HDI)

\section{The Samples}

The samples are HDI, FTT, EDUGE, HEGE North Sumatra Province in 20102019. The data used in this study are in North Sumatra Province, and time series for 10 years, from 2010 - 2019. With the total amount of data by combining cross sections and time series in the form of panel data into as many as 40 analysis data.

\section{Data Analysis Method}

Data Analysis Technique used in this study is multiple linear regression analysis with themethod Ordinary Least Square (OLS)and usesdata from time series North Sumatra Province in 2005-2019. The general form of multiple regression is as follows:

HDI $=f(F T$, EDUGE, HEGE)

$Y \quad=f(X 1, X 2, X 3,) \ldots(1)$

Econometrically, equation (1) is changed to show the relationship between the independent variable and the dependent variable which is analyzed using multiple regression analysis techniques with The regression equation is as follows:

$\mathrm{HDI}=\beta 0+\beta 1 \mathrm{LnFTT}+\beta 2 \mathrm{LnEDUGE} \beta 3 \mathrm{LnHEGE}+\cdot \ldots(2)$

Where :

HDI : Human Development Index

FTT : Farmer Exchange Rate

EDUGE : Government Expenditure for Education

HEGE : Government Expenditure for Health

BO : Constants

$\beta 1 \ldots \beta 3$ : Regression Coefficient

The method used in this study is the inductive statistical method (inferential statistics). Inferential statistics are statistics that have the task of analyzing and drawing conclusions and making decisions based on the analysis that has been carried out, which are included in inferential statistics, including making predictions and testing hypotheses. Inferential statistics are concerned with data modeling and making decisions based on data analysis, for example conducting hypothesis testing, estimating future observations (estimates or predictions), making modeling (correlation, regression, anova, time series), etc. 


\section{RESULTS AND DISCUSSION}

\section{Overview}

The Human Development Index Indonesia, Value Added Farmer, Government Expenditures For Education and Public Spending for Health can be seen in the following table:

Table 1. Data of HDI, FER, Expenditure for Education and Expenditure for Health

\begin{tabular}{ccccc}
\hline Year & $\begin{array}{c}\text { Human } \\
\text { Development } \\
\text { Index }\end{array}$ & $\begin{array}{c}\text { Farmer Exchange } \\
\text { Rate (price } \\
\text { indeks) }\end{array}$ & $\begin{array}{c}\text { Government } \\
\text { Expenditure for } \\
\text { Education (in } \\
\text { millions IDR) }\end{array}$ & $\begin{array}{c}\text { Government } \\
\text { Expenditure for } \\
\text { Health (in millions } \\
\text { IDR) }\end{array}$ \\
\hline 2010 & 67,09 & 102,36 & 6690,89 & 2500,42 \\
2011 & 67,34 & 103,42 & 7011,17 & 2900,54 \\
2012 & 67,74 & 101,71 & 7357,22 & 3207,55 \\
2013 & 68,36 & 99,49 & 7970,45 & 3554,52 \\
2014 & 68,87 & 100,08 & 8478,26 & 3793,27 \\
2015 & 69,51 & 98,61 & 8904,74 & 4066,72 \\
2016 & 70,00 & 100,19 & 9341,37 & 4366,28 \\
2017 & 70,57 & 99,39 & 9802,14 & 4699,93 \\
2018 & 71,18 & 97,98 & 10418,75 & 4977,05 \\
2019 & 71,74 & 98,08 & 10924,95 & 5207,26 \\
\hline
\end{tabular}

Source : Data BPS

On The table above from 2010 to 2019 the human development index has increased quite significantly. This is a problem for the Province of North Sumatra, so it is necessary to do something on an ongoing basis so that the human development index (HDI) will increase. In the table above, the exchange rate of farmers in particular experiencing the fluctuation of farmer welfare needs to be a concern because it is related to the future of farmers in sustainable production and the ability to exchange agricultural products.

Provincial government spending on the education and health sectors has generally increased, but the amount is still below other sectors. This clearly illustrates that the government still lacks attention to the education and health sectors.

The results of the data normality test can be seen using the Kolmogorov-Smirnov test method. The results are as follows:

26 | Zulkarnain Nasution, Khairul Rizal, Junita Lubis; Effect Term of Trades,

Government... 
Table 2. Normality Test Results (One-Sample Kolmogorov-Smirnov Test)

\begin{tabular}{llrrrr}
\hline & & HDI & FIT & EDUGE & HEGE \\
\hline $\mathrm{N}$ & & 10 & 10 & 10 & 10 \\
& Mean & 69.240000 & 4.613329 & 9.057303 & 8.263223 \\
Normal Parameters & & & & \\
& Std. & 1.6270901 & .0224567 & .1680793 & .2619324 \\
& Deviation & & & & .120 \\
Most Extreme Differences & Absolute & .122 & .210 & .074 \\
& Positive & .122 & .210 & .120 & .071 \\
& Negative & -.093 & -.102 & -.093 & -.074 \\
Kolmogorov-Smirnov Z & & .385 & .663 & .380 & .235 \\
Asymp. Sig. (2-tailed) & & .598 & .771 & .499 & 310 \\
\hline
\end{tabular}

a. Test distribution is Normal.

Based on the data normality test using the Kolmogorov-Smirnov, the Asymp value was obtained. Sig. (2-Tailed) each of the variables X1 0.771, X2 0.499, X3 0.310, $Y 0.598$ which is greater than 0.05 , it can be concluded that the data is normally distributed.

Table 3 Multicollinearity Test Results

\begin{tabular}{llcl}
\hline \multirow{2}{*}{ Model } & & Coefficients $^{\text {a }}$ & \\
& & Tolerance $^{\text {Collinearity Statistics }}$ & VIF \\
& (Constant) & & \\
& FTT & .660 & 1.515 \\
& EDUGE & .713 & 6.504 \\
& HEGE & .713 & 7.422 \\
\hline
\end{tabular}

a. Dependent Variable: IPM

From the table of coefficients the value at the output shows the results of the indication of multicollinearity

If VIF $<10,00$ then there is no indication of Multicolinearity

If VIF $>10,00$ then no Multicolinearity indication.

Result:

Tolerance value : X1 Farmer Exchange Rate $=0,660$

X2 Educational Services Output $\quad=0,713$

X3 Health Services output $\quad=0,713$

VIF X1 Farmer Exchange Rate $\quad=1,515$

X2 Educational Services Output $\quad=6,504$

X3 Health Services output $\quad=7,422$

From the table above, it can be seen that none of the data is multicorelated so that it can be continued with the autocorrelation test. 
Table 4 Data Autocorrelation Test

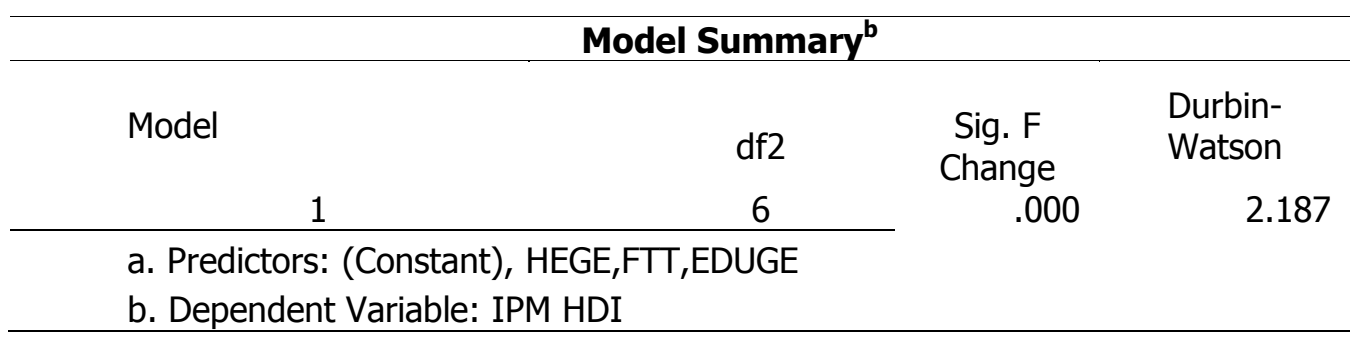

In the regression analysis, it can be seen that the $\mathrm{DW}$ value is 2.187 and the $\mathrm{DL}$ value is 0.3760 and $\mathrm{DU}$ 2.4137. $\mathrm{DL}<\mathrm{DW}<\mathrm{i}$.e. $0.3760 \mathrm{DL}, 2.187 \mathrm{DW}, 2.4137 \mathrm{DU}$. The value between the DL and DU and is at the point of doubt. So it can be concluded that there are symptoms of weak autocorrelation.

Table 5. Contribution and free correlation to the dependent variable

\begin{tabular}{|c|c|c|c|c|c|c|}
\hline \multicolumn{7}{|c|}{ Model Summary } \\
\hline \multirow[b]{2}{*}{ Model } & \multirow[b]{2}{*}{$\mathrm{R}$} & \multirow[b]{2}{*}{ R Square } & \multirow{2}{*}{$\begin{array}{l}\text { Adjusted R } \\
\text { Square }\end{array}$} & \multirow{2}{*}{$\begin{array}{l}\text { Std. Error of } \\
\text { the Estimate }\end{array}$} & \multicolumn{2}{|c|}{ Change Statistics } \\
\hline & & & & & $\begin{array}{l}\text { R Square } \\
\text { Change }\end{array}$ & F Change \\
\hline 1 & $.898^{\mathrm{a}}$ & .897 & .895 & .1101228 & .897 & 65.923 \\
\hline
\end{tabular}

a. Predictors: (Constant), HEGE, FTT, EDUGE

b. Dependent Variable: HDI

Identifying the effect of the independent variable farmer exchange rate, government spending on education and government spending on health together on the HDI independent variable can be seen in the table above, at the value of $R$ square. The magnitude of the value of $R$ square (R2) in the table is 0.897 . This number has a significant influence on FER, education expenditure and health expenditure. which means the magnitude of the factors that affect the HDI is 89.7 while the remaining $10.3 \%$ is influenced outside the model studied.

Table 6 The effect of independent variables on the dependent variable

\begin{tabular}{|c|c|c|c|c|c|c|}
\hline \multicolumn{7}{|c|}{ Coefficients $^{\mathrm{a}}$} \\
\hline \multirow{2}{*}{\multicolumn{2}{|c|}{ Model }} & \multicolumn{2}{|c|}{$\begin{array}{l}\text { Unstandardized } \\
\text { Coefficients }\end{array}$} & \multirow{2}{*}{$\begin{array}{c}\text { Standardized } \\
\text { Coefficients } \\
\text { Beta } \\
\end{array}$} & \multirow[t]{2}{*}{$\mathrm{t}$} & \multirow[t]{2}{*}{ Sig. } \\
\hline & & $B$ & Std. Error & & & \\
\hline \multirow{4}{*}{1} & (Constant) & -66.420 & 14.938 & & -4.446 & .004 \\
\hline & FER & 6.418 & 2.012 & .089 & 3.190 & .019 \\
\hline & PPP & 14.420 & 1.910 & 1.490 & 7.549 & .000 \\
\hline & PPK & -2.971 & 1.207 & -.478 & -2.461 & .049 \\
\hline
\end{tabular}

a. Dependent Variable: HDI

28 | Zulkarnain Nasution, Khairul Rizal, Junita Lubis; Effect Term of Trades,

Government... 
In the SPSS calculation listed in the Coefficients table above where the $t$ table is to show that the linear effect of the farmer exchange rate variable and the dependent variable HDI is 3.190. The results of the SPSS calculation show the $t$ calculated of 3.190 > $\mathrm{t}$ table of 2.997. thus the decision is Ho is rejected and $\mathrm{H} 1$ is accepted. This means that there is a linear effect, the independent variable, the added value of farmers, has an effect on the dependent variable on HDI. In the SPSS calculation listed in the Coefficients table above where the $t$ table is to show that the linear effect of the education expenditure variable and the HDI dependent variable is 7.549.

The results of the SPSS calculation show that the $t$ calculated is 7.549> $t$ table is 2.997. thus the decision is $\mathrm{Ho}$ is rejected and $\mathrm{H} 1$ is accepted. This means that there is a linear effect of the independent variable on government spending on the HDI dependent variable.

In the SPSS calculation listed in the Coefficients table above where the t table is to show that the linear effect of the health expenditure variable and the HDI dependent variable is -2.461 . The results of the SPSS calculation show that the $t$ calculated is $2.461>$ the $\mathrm{t}$ table is 2.997. thus the decision is $\mathrm{H} 1$ is rejected and Ho is accepted. This means that there is no linear effect, the independent variable on health expenditures has an effect on the HDI dependent variable.

Table 7 Eligibility of the Regression Model

ANOVA $^{\text {b }}$

\begin{tabular}{rrrrrrr}
\hline & Model & Sum of Squares & df & Mean Square & F & \multicolumn{1}{c}{ Sig. } \\
\hline 1 & Regression & 3.754 & 3 & 1.918 & 6.923 & $.000^{\mathrm{a}}$ \\
Residual & .073 & 6 & .012 & & \\
Total & 3.827 & 9 & & &
\end{tabular}

a. Predictors: (Constant), HEGE, FTT, EDUGE

b. Dependent Variable: HDI

Calculating the value of $\mathrm{F}$ table with the provisions of the value of significance level of 0.05 and the value of Degree Of Freedom with the provisions of Numerature / vector 1: number of variables -1 or $4-1=3$, and dumerator / vector 2 : number of cases number of variables or $10-4=6$. With these provisions, the $\mathrm{F}$ table number is obtained at 3.71 .

The results of calculations with SPSS obtained the $\mathrm{F}$ calculated of $6.923>\mathrm{F}$ table of 3.71. Thus $\mathrm{Ho}$ is rejected and $\mathrm{H} 1$ is accepted, meaning that there is a linear relationship between the independent variables of farmer value added, education expenditure and health expenditure with the dependent variable HDI. With a sig value of 0,000 the conclusion is that the regression model above is feasible and correct.

\section{The effect of added value of farmers on HDI in North Sumatra}

The results of the research on the effect of FTT on HDI in North Sumatra Province showed an insignificant and negative effect. This can be seen through the results of the $t$ test which shows that the probability value of FTTER is $0.019<0.05$, so it can be concluded that FTT has a significant effect on HDI. The FTT coefficient is 
6,418 , which means that if the FTT value increases by $5 \%$, the HDI will increase by $32.09 \%$.

The increase in HDI in the province of North Sumatra is more due to government spending on education and health for the allocation of HDI. Although there is an increase in household income, farmers indicate that they are able to meet the needs in the education and health sectors. However, if education and health facilities as indicators of the success of human development are not evenly available and services are not optimal, then the result will be the same. There will be a significant effect of increasing income on efforts to increase farmers' HDI. This shows that the growth of FTT has a great influence on the increase in HDI in North Sumatra Province.

This study is in accordance with the results of research (Rosidi, 2007) which states that if the price index received by farmers is greater than the percentage of the price index paid by farmers, the FTT will increase and then the farmer's income will increase greater than the level of expenditure. This shows that there is a relationship between FTT and increased farmer income which is closely related to the level of welfare. This study contradicts the results of the Balitbang study in North Sumatra province (2011) which states that the FER variable has no significant effect on the expansion of employment opportunities in the agricultural sector in North Sumatra in the period 1988-2009. The estimation results in the research of Balitbang propinsu North Sumatra explained that although the FTT index increased, the price of basic necessities also increased more rapidly so that the growth rate was very slow.

\section{The Effect of Government Expenditure on Education on HDI in North Sumatra Province}

Based on data analysis and hypothesis testing that has been carried out in this study, it can be seen that the education sector government expenditure variable has a positive and significant effect on the human development index in North Sumatra province. This can be seen from the results of the study the probability value is 0.000 $<0.05$, so it can be concluded that government spending on education has a significant effect on HDI. The coefficient of government spending on education is 14,420 , which means that if the value of government spending on education increases by $5 \%$, the HDI will increase by 72.1 .

Government spending on education by building educational infrastructure and providing educational services to all population of North Sumatra is evenly distributed. The education budget of $20 \%$ of the APBD percent represents the realization of the government for education.

The government places education as an important factor in supporting national development. This can be seen from the large amount of government spending on the education sector so that it can be realized in all parts of the education sector so that the human development index in the province of North Sumatra can increase better and sees a greater growth in the increase in the human development index in North Sumatra Province.

This study is in accordance with research conducted by Tri Mariani (2010) and Devyanti, (2012) where it is stated that government spending on education has a positive and significant effect on the human development index (HDI). 


\section{The Effect of Government Expenditure on Health on HDI in North Sumatra Province}

Based on the data analysis and hypothesis testing conducted in this study, it can be seen that the health sector government expenditure variable has a positive and significant effect on the human development index in North Sumatra province. It can be seen from the results of the study the probability value is $0.049<0.05$, so it can be concluded that government spending in the health sector has a significant effect on HDI. The coefficient of government spending in the health sector is $-2,971$, which means that if the value of government spending in the health sector increases by $5 \%$, the HDI will decrease by $-14.855 \%$.

A smaller proportion of funds in the education sector will cause government spending in the health sector to be less able to increase the human development index. Due to the small amount of government spending in the health sector in the province of North Sumatra, that the budget spent on the health sector has not been properly realized, this is seen because of the lack of government spending and to be able to go directly to improve health equipment and equipment facilities so that the provincial level of human development index North Sumatra could do better and see a greater growth in the increase in the human development index.

This is in accordance with the research conducted by Astri Meylina (2013) and Sanggelorang (2015) which states that government spending in the health sector does not have a positive and significant effect on the human development index.

\section{CONCLUSIONS AND POLICY IMPLICATIONS}

\section{Conclusions}

Based on the results of the analysis and discussion that has been described, the following conclusions can be drawn:

1. The results of this study indicate that FER has a significant and positive effect on HDI. The reason is because FER continues to increase, which shows that farmers' income has also increased. This will have an impact on inflation which causes the prices of goods for education and health needs to also increase, so that the farming community is able to prioritize their expenditure for spending in order to improve the quality of human resources.

2. The results of this study indicate that government spending on education has a significant and positive effect on HDI. The reason is because government spending on education continues to experience a significant increase so that the human education index has increased quite significantly in the province of North Sumatra.

3. The results of this study indicate that government spending on health has a negative and insignificant effect on the human development index. The reason is because government spending has not been able to help increase the human development index in North Sumatra Province, this is because the provincial government of North Sumatra has built several health facilities in the last few years so that it takes up a lot of the budget. 


\section{REFERENCES}

Andhini, N. F. (2017). Pola Hubungan Pertumbuhan Ekonomi Dan pembangunan manusia Dipropinsi Jawa Timur Tahun 2007-2011. Journal of Chemical Information and Modeling, 53(9), 1689-1699.

Baeti, N. (2013). Pengaruh Pengangguran, Pertumbuhan Ekonomi, Dan Pengeluaran Pemerintah Terhadap Pembangunan Manusia Kabupaten/Kota Di Provinsi Jawa Tengah Tahun 2007-2011. Economics Development Analysis Journal, 2(3), 85-98. https://doi.org/10.15294/edaj.v2i3.1984

Bambang bemby, S Abdul Bashir. (2017). analisis tipologi hubungan antara indeks pembangunan manusia dan pertumbuhan ekonomi di propinsi sumatera selatan. 266. https://opac. perpusnas.go.id/DetailOpac. aspx?id=969369

Brata, A. G. (2002). Jurnal EKONOMI PEMBANGUNAN. Jurnal Ekonomi Pembangunan, $7(2), 113-122$.

Devyanti. Patta (2012). Analisis faktor-faktor yang mempengaruhi indeks pembangunan manusia di Sulawesi Selatan periode 2001-2010. Jurnal: Universitas Hasanudin.

K, Johana. Maria. (2011). Analisis Pengaruh Pengeluaran Pemerintah di Sektor Pendidikan danKesehatan Terhadap Pengetasan Kemiskinan Melalui Peningkatan Pembangunan Manusiadi Provinsi Jawa Tengah.Jurnal Dinamika Ekonomi Pembangunan.Volume 1, No. 1. Hal25-41. 1(1), 2011.

Lugastoro, D. P. (2013). ANALISIS PENGARUH PAD DAN INDEKS PEMBANGUNAN MANUSIA KABUPATEN / KOTA DI JAWA TIMUR SKRIPSI

Mahbub UI Hag. (1999). Reflections on Human Development, Delhi, Oxford University Press

Mangkoesoebroto. (1993). Ekonomi Publik. Yogyakarta: BPFE.

Napitupulu. (2007). Pengaruh Indiaktor Komposit Indeks Pembangunan Manusia Terhadap Penurunan Jumlah Penduduk Miskin Di Sumatera Utara. 9(1), 7699.

Rosidi. (2007). Rosidi, A. 2007. Nilai Tukar Petani (NTP) sebagai Indikator Tingkat Kesejahteraan Petani. Makalah Pertemuan dan Diskusi Terbatas Mengenai Nilai Tukar Petani (N TP) II , Bogor, 15 Maret 2007. Pusat Analisis Sosial Ekonomi dan Kebijakan Pertanian. Bogor.

Ruauw. (2010). NIlai Tukar Petani Sebagai Indikator Kesejahteraan Petani. Jurnal Penelitian ASE, 6 (2), 1-8..

Sanggelorang, S. M. M., Rumate, V. A., \& Siwu, F. D. J. (2015). PENGARUH

PENGELUARAN PEMERINTAH DI SEKTOR PENDIDIKAN DAN KESEHATAN

TERHADAP INDEKS PEMBANGUNAN MANUSIA DI SULAWESI UTARA

Http://Www.Sulutprov.Go.Id/Mengenal-Sulut/Sejarah/, 15(02), 1-11.

Simatupang. (1992). pertumbuhan ekonomi dan nilai tukar barter sektor pertanian. Japanese Society of Biofeedback Research, 19(5), 463-466.

Statistik, (2019). badan Pusat Statistik (Issue April).

Todaro. (2000). Todaro, Michael, P. 2000. Pembangunan Ekonomi di Dunia Ketiga.

Edisi Ketujuh diterjemahkan oleh Haris Munandar. Penerbit Erlangga. Jakarta.

UNDP. (1990). Global Human Development Report.Human Resources Department .

32 | Zulkarnain Nasution, Khairul Rizal, Junita Lubis; Effect Term of Trades, Government ... 